\title{
Upaya Meningkatkan Hasil Belajar Dan Kemampuan Gerak Dasar Permainan Rounders Melalui Strategi Pembelajaran Berpasangan Siswa Kelas V SD Negeri 112 Pacciro Kabupaten Bone
}

\author{
Haderiah \\ Dinas Pendidikan Kabupaten Bone \\ Email: haderiah@gmail.com
}

\begin{abstract}
Abstrak. Permasalahan pada penelitian ini adalah sebagian besar siswa kurang dalam gerak dasar pada permainan rounders. Upaya yang dilakukan adalah dengna menerapkan strategi pembelajaran berpasangan. Tujuan penelitian ini untuk meningkatkan kemampuan gerak dasar permainan rounders melalui strategi berpasangan di kelas V SD Negeri 112 Pacciro Kecamatan Ajangale Kabupaten Bone Tahun Pelajaran 2017/2018. Adapun objek penelitian adalah peningkatan kemampuan lempar tangkap bola pada permainan bola Rounders. Waktu penelitian selama 6 bulan. Teknik pengumpulan data dengan metode observasi, tes dan dokumentasi. Data yang sudah diperoleh kemudian dipaparkan dengan menggunakan statistik deskriptif. Dari hasil penelitian tindakan kelas yang dilaksanakan bahwa penerapan strategi pembelajaran berpasangan berdampak positif pada peningkatan kemampuan lempar tangkap bolasiswa kelas V SD Negeri 112 Pacciro Kecamatan Ajangale Kabupaten Bone Tahun Pelajaran 2017/2018, hal ini dapat dibuktikan peningkatan hasil belajar siswa yang ditandai dengan peningkatan hasil dan ketuntasan belajar siswa dalam setiap siklus. Jadi dapat disimpulkan bahwa penerapan strategi pembelajaran berpasangan terbukti mampu meningkatkan kemampuan gerak dasar lempar tangkap bola pada permainan rounders KELAS V SD Negeri 112 Pacciro Kecamatan Ajangale Kabupaten Bone Tahun Pelajaran 2017/2018.
\end{abstract}

Kata kunci: berpasangan, kemampuan, lempar tangkap bola

\begin{abstract}
The problem in this study is that most students lack basic motion in the rounders game. The effort taken is to implement a pairing learning strategy. The purpose of this study was to improve the basic mobility of rounders through pairing strategies in the fifth grade of SD Pacciro Elementary School, Ajangale District, Bone District 2017/2018 Academic Year. The object of the research is an increase in ball catching abilities in Rounders ball games. Research time for 6 months. Data collection techniques using observation, test and documentation methods. The data that has been obtained is then presented using descriptive statistics. From the results of classroom action research carried out that the application of the pairing learning strategy had a positive impact on improving the scholarship throwing ability of the fifth grade of SD Negeri 112 Pacciro Ajangale Subdistrict Bone District 2017/2018 Academic Year, this can be proven to increase student learning outcomes characterized by increased yields and completeness of student learning in each cycle. So it can be concluded that the application of paired learning strategies is proven to be able to improve the basic motion ability of ball catching at rounders game CLASS V SD Negeri 112 Pacciro Ajangale District Bone District 2017/2018 Academic Year.
\end{abstract}


Keywords: pairing, ability, throwing a ball

\section{PENDAHULUAN}

Pendidikan jasmani, olahraga, dan kesehatan yang diajarkan disekolah dasar memiliki peran untuk memberikan pengalaman kepada peserta didik untuk belajar melalui aktivitas jasmani, olahraga, dan kesehatan terpilih yang dilaksanakan sebagai bagian dari pendidikan secara keseluruhan. Pendidikan jasmani, olahraga, dan kesehatan merupakan media untuk mendorong pertumbuhan fisik, perkembangan psikis, keterampilan motorik, pengetahuan dan penalaran, penghayatan nilainilai (sikap, mental, emosional, sportivitas, spiritual, sosial), serta pembiasaan pola hidup sehat yang bermuara untuk merangsang pertumbuhan dan perkembangan kualitas fisik dan psikis yang seimbang.

Untuk itu, kegiatan olahraga perlu ditingkatkan dan disebarluaskan diseluruh pelosok tanah air dalam rangka memasyarakatkan olahraga dan mengolahragakan masyarakat dengan tujuan untuk mencapai terwujudnya manusia Indonesia seutuhnya yang selaras, serasi, seimbang antara pertumbuhan jasmani dan perkembangan rohani. Sehingga menjadi manusia Indonesia yang kuat, sehat, segar, terampil, cerdas, bersemangat, disiplin, berprestasi, berkepribadian, dan bertaqwa kepada Tuhan Yang Maha Esa, serta mempererat persahabatan antar bangsa-bangsa di dunia, serta menjunjung tinggi kebesaran olahraga dan martabat bangsa.

Dalam rangka mencapai hal di atas, maka desain pembelajaran menjadi sangat penting. Proses belajar mengajar merupakan inti dari proses pendidikan secara keseluruhan dengan guru sebagai pemeran utama atau aktornya pendidikan. Hal ini mengandung arti bahwa berhasil tidaknya pencapaian tujuan pendidikan tergantung pada kreativitas guru dalam melaksanakan proses pembelajaran khususnya dalam menyampaikan materi. Jika dihubungkan dengan kreativitas guru maka salah satunya adalah bagaimana guru menggunakan metode pembelajaran sehingga dapat meningkatkan kemampuan serta tidak hanya menguasai teori saja melainkan mampu untuk mengaplikasikan dilapangan. Pembelajaran ini sangat penting dalam penyampaian atau penyajian materi pelajaran yang dapat mendukung serta memotivasi siswa dalam menerima materi. Kriteria keberhasilan proses belajar mengajar ditandai dengan terjadinya perubahan tingkah laku dan peningkatan pengetahuan pada diri ndividu yang belajar. Untuk mencapai kriteria ini adalah tugas dan peran guru dalam memilih dan menggunakan metode yang kreatif dalam meningkatkan keberhasilan belajar siswa dalam pelaksanaan pembelajaran.

Penggunakan metode, model dan pendekatan yang tepat dan sesuai dengan kondisi sekolah, maka tujuan pembelajaran penjaskes akan dapat dicapai. Akan tetapi yang menjadi masalah adalah sarana yang digunakan dalam materi penjaskes itu sendiri kurang sesuai dengan kondisi siswa yang ada disekolah, sehingga akan menjadi kendala terhadap keberhasilan proses pembelajaranya. Dengan demikian maka tujuan dari pembelajaran tersebut tidak akan dapat terwujud dengan baik. Untuk mewujudkan tujuan Panjaskes tersebut maka pembelajaran Penjaskes harus diajarkan menggunakan metode, model dan pendekatan yang sesuai dengan kondisi sekolah yang bersangkutan.

Modifikasi model pembelajaran dalam Penjaskes sangat penting untuk diketahui dan dilaksanakan oleh para guru pendidikan jasmani. Dengan modifikasi siswa memperoleh kepuasan dalam mengikuti pelajaran, meningkatkan kemungkinan keberhasilan dalam partisipasi, siswa dapat melakukan pola gerak secara benar (Lutan,1988). Pendekatan modifikasi ini dimaksudkan agar materi yang ada di dalam kurikulum dapat disajikan sesuai dengan tahapan perkembangan kognitif, afektif, dan psikomotor siswa. Upaya yang bisa dilakukan adalah dengan modifikasi pembelajaran berupa penggunaan permainan. Salah satu permainan yang bisa di gunakan adalah permainan Rounders.

Permainan Rounders merupakan salah satu permainan bola kecil. Permainan ini dimainkan oleh dua regu, yakni regu pemukul dan regu penjaga. Regu pemukul berusaha mendapat nilai dengan memukul bola kemudian berlari mengelilingi lapangan. Sebaliknya, regu penjaga berusaha menangkap bola serta mematikan regu pemukul. Regu yang banyak mengumpulkan nilai menjadi pemenangnya. Permainan sederhana ini dapat dimainkan dilapangan yang tidak begitu luas.

Permainan Rounders merupakan permainan beregu menggunakan bola kecil yang 
dipukul menggunakan tongkatpemukul.Menurut Dadan Heryana dan Giri Verianti (2010:67-72), keterampilan dasar yang diperlukan dalam bermain Rounders meliputi:melempar bola, memukul bola, menangkap bola dan kecepatan lari. Permainan inimenjadi semakin menarik apabila pemain menguasai kemampuan melempar bola, menangkap bola, memukul bola, dan kecepatan lariyang baik. Dalam pembelajaran penjas disekolah dasar, permainanRoundersmenjadi materi yang tidak hanya memberikan pengalaman gerak manipulative, akan tetapi juga melatih kerjasama dan sikap sportivitas. Alat yang dibutuhkan dalam permainan Rounders adalah bola dan alat pemukul dan bola terbuat dari karet alat pemukul terbuat dari kayu. Bentuk lapangan Rounders adalah persegi empat yang dilengkapi tiang perhentian dan ukuran lapangan dapat disesuaikan dengan ukuran lapangan yang ada atau dengan situasi keadaan setempat.

Permainan ini bermanfaat untuk melatik ketangkasan, ketepatan, kecepatan, keberanian, koordinasi antara melempar, menangkap, dan berlari. Jadi permainan ini boleh dijadikan dasar dalam berolahraga karena banyak sekali terdapat untuk membentuk unsur-unsur kesegaran jasmani. Bermain dengan menggunakan alat bola adalah suatu jenis permainan yang paling menarik diantara permainan yang menggunakan alat. Entah itu menggunakan bola kecil seperti permainan Rounders. Tidak aneh apabila sebagian besar untuk permainan yang ada dalam olahraga menggunakan bola sebagai alat. Dalam memainkan bola, ada sejumlah keterampilan dasar yang sifatnya umum yang digunakan dalam memainkan sebuah bola.

Berdasarkan observasi awal di Kelas V SD Negeri 112 Pacciro Tahun Pelajaran 2017/2018 khususnya Kelas V yang berjumlah 23 orang, hasil menunjukkan bahwa sebagian besar siswa kurang dalam gerak dasar lempar tangkap bola pada permainan Rounders. Dari hasil observasi awal dengan jumlah siswa 23 orang, yang baik melakukan hanya 13 siswa atau $56,52 \%$ sedangkan yang cukup 7 siswa atau $30,43 \%$ dan kurang 3 siswa atau 13,04\% dengan ketuntasan berdasarkan hasil tes formatif sebanyak 4 siswa atau 17,39\% dan nilai rata-rata hasil belajar sebesar 56,52. Hasil ini lebih membuktikan bahwa kekurangmampuan siswa dalam melakukan teknik pada permainan Rounders ini disebabkan para guru di sekolah hanya menerapkan metode ceramah dan bermain tanpa menggunakan metode atau siswa hanya diberikan bola dan dibiarkan secara individual tanpa bimbingan dan arahan.

Berdasarkan permasalahan yang Telah dikemukakan sebelumnya penulis tertarik untuk mengadakan penelitian dengan judul "Upaya Meningkatkan Hasil Belajar dan Kemampuan Gerak Dasar dalam Permainan Rounders melalui Strategi Pembelajaran Berpasangan Siswa Kelas V SD Negeri 112 Pacciro Semester I Tahun Pelajaran 2017/2018"

\section{METODE PENELITIAN}

Jenis Penelitian penelitian ini menggunakan rancangan penelitian tindakan kelas (Classroom Action Reseach) metode ini memfokuskan penelitian dalam bentuk tindakan kelas yakni penelitian yang dilakukan bukan menciptakan yang baru semata, tetapi menempelkan pada suatu kegiatan yang sedang berlangsung. Dalam penelitian tindakan ini, peneliti melakukan suatu tindakan yang secara khusus diamati terus menerus, dilihat plusminusnya, kemudian diadakan pengubahan terkontrol sampai pada upaya maksimal dalam bentuk tindakan yang paling tepat. (Suharsimi Arikunto, 2006:3).

Penelitian tindakan kelas ini bertempat di kelas V SD Negeri 112 Pacciro yang beralamat di Jalan Poros Soppeng Desa Pacciro Kecamatan Ajangale Kabupaten Bone, Sedangkan waktu penelitian adalah pada SD Negeri 112 Pacciro Semester I Tahun Pelajaran 2017/2018yang dilaksanakan dari bulan Mei 2017 sampai dengan bulan Oktober 2017 selama 6 bulan. Subjek dalam penelitian ini adalah siswa kelas V SD Negeri 112 Pacciro Semester I Tahun Pelajaran 2017/2018 yang berjumlah 23 siswa .

Penelitian tindakan kelas ini dilakukan dengan menerapkan siklus yang berkelanjutan. Penelitian ini dilaksanakan sampai pembelajaran berhasil, tiap siklus dilakukan dua kali pertemuan selama 4 x 35 menit. Pelaksanaan siklus kedua merupakan perbaikan dari siklus pertama yang belum mencapai keberhasilan. Tiap siklus terdiri dari empat tahapan yaitu: (1) tahap perencanaan, (2) tahap pelaksanaan tindakan, (3) tahap pengamatan, dan (4) tahap refleksi.

Teknik pengumpulan data yang digunakan dalam penelitian ini adalah observasi, dokumentasi dan teknik tes.

\section{Observasi}

Menurut Wardhani $(2007 ; 2.25)$, metode observasi adalah jenis observasi yang 
menggunakan instrument instrument observasi yang sudah tersusun sebelumnya dan siap dipakai sehingga pengamat lebih mudah didalam menggunakanya. Data yang diambil dengan metode observasi ini berupa pelaksanaan tindakan saat pembelajaran. Data dari metode ini nantinya akan turut menentukan bagaimana pelaksanaan pembelajaran berpasangan lempar tangkap bola pada permainan bola Rounders, apakah sudah sesuai dengan yang telah direncanakan atau belum.

\section{Metode Dokumentasi}

Teknik dokumentasi merupakan kegiatan perekaman bukti dari segala tindakan yang dilaksanakan selama kegiatan penelitian berlangsung. Kegiatan yang didokumentasikan antara lain kegiatan yang dilakukan oleh peneliti maupun kegiatan yang dilakukan oleh siswa serta kegiatan lain yang mendukung berlangsungnya penelitian seperti aktivitas siswa dalam pembelajaran siswa, unjuk kerja dan lain sebagainya. Semua kegiatan tersebut direkam melalui kamera foto yang dilakukan oleh teman sejawat peneliti.

3. Tes

Tes dilaksanakan pada akhir pembelajaran dari setiap siklus. Dengan memberikan soal kepada siswa untuk mengetahui pemahaman siswa terhadap materi yang dipelajari.

Dalam penelitian ini validitas data dilakukan dengan teknik triangulasi. Triangulasi dilakukan dengan maksud untuk mengecek kebenaran data yang diperoleh dan membandingkannya dengan data yang diperoleh dari sumber lain. Triangulasi sumber data dilakukan untuk mengecek kebenaran data dari guru kelas maupun anak. Sedangkan triangulasi metode dilakukan dengan menggunakan teknik pengumpulan data yang berbeda untuk mendapatkan data yang sama. Observasi dapat dicek kebenarannya dari arsip atau dokumen dan tes hasil belajar siswa

Data yang sudah diperoleh kemudian di paparkan dengan menggunakan statistik deskriptif. Menurut Sugiyono (2006:21) statistik deskriptif ialah statistik yang berfungsi untuk mendiskriptifkan atau memberikan gambaran terhadap objek yang diteliti melalui data sampel atau populasi sebagaimana adanya, kemudian membuat kesimpulan yang berlaku umum. Tehnik analisa data dalam penelitian ini dilakukan oleh peneliti bersama dengan kolabolator untuk merefleksi hasil observasi dan angket terhadap proses pembelajaran yang dilaksanakan oleh guru dan siswa.

Analisis data adalah data dari seluruh responden atau sumber data lain terkumpul. Analisis data dilaksanakan secara kualitatif dan kuantitatif pada setiap akhir siklus pembelajaran serta data hasil belajar siswa, data yang dianalisis meliputi data hasil observasi siswa

1. Data Hasil Observasi Siswa

Komponen-komponen yang diamati atau dinilai dari aktivitas siswa adalah kegiatan belajar mereka selama mengikuti pembelajaran.

Tabel 3.2 Kriteria Penilaian Hasil Observasi Siswa

\begin{tabular}{l|l|l|l} 
No & $\begin{array}{l}\text { Rentang } \\
\text { Skor }\end{array}$ & $\begin{array}{l}\text { Kriteria } \\
\text { Nilai }\end{array}$ & Keterangan \\
\hline $\mathbf{1}$ & $90-100$ & $\begin{array}{l}\text { Sangat } \\
\text { Baik }\end{array}$ & Tuntas \\
\hline $\mathbf{2}$ & $80-89$ & Baik & Tuntas \\
\hline $\mathbf{3}$ & $70-79$ & Cukup & Belum Tuntas \\
\hline $\mathbf{4}$ & $60-69$ & Kurang & Belum Tuntas \\
\hline $\mathbf{5}$ & $<=50$ & $\begin{array}{l}\text { Sangat } \\
\text { Kurang }\end{array}$ & Belum Tuntas
\end{tabular}

2. Data Hasil Tes

Kriteria penilaian hasil tes tertulis sebagaimana dijelaskan pada tabel di bawah ini. Tabel 3.3 Kriteria Penilaian Hasil Tes Kognitif

\begin{tabular}{c|l|l} 
No & $\begin{array}{l}\text { Rentang } \\
\text { Skor }\end{array}$ & Keterangan \\
\hline $\mathbf{1}$ & $<70$ & Belum Tuntas \\
\hline $\mathbf{2}$ & $>=70$ & Tuntas
\end{tabular}

Pelaksanaan Penelitian Tindakan Kelas (PTK) ini dilaksanakan dalam siklus I sampai siklus ke-n. Tiap siklus dilaksanakan sesuai dengan refleksi dari siklus sebelumnya. Prosedur pelaksanaan dalam tahap ini meliputi (1) Perencanaan (2) Pelaksanaan (3) Pengamatan (4) Refleksi.

Kriteria untuk mengukur tingkat keberhasilan adalah sebagai berikut.

1. Proses perbaikan pembelajaran dinyatakan berhasil apabila $85 \%$ dari jumlah siswa mengalami peningkatan hasil belajarnya selama proses pembelajaran berlangsung minimal mendapat nilai 70

2. Proses perbaikan pembelajaran dinyatakan berhasil apabila 85\% dari jumlah siswa mengalami peningkatan kemampuan gerak dasar dalam permainan Rounders. 
HASIL DAN PEMBAHASAN

\section{Deskripsi Pra Siklus}

Sebelum melaksanakan proses penelitian, terlebih dahulu peneliti melakukan kegiatan observasi yang dilakukan sebelum siklus I untuk mengetahui keadaan nyata yang ada di lapangan. Proses pembelajaran belum melibatkan anak yang kreatif, model pembelajaran,dan media pembelajaran yang kurang sesuai. Guru kurang kreatif dan inovatif dalam memodifikasi alat-alat untuk pembelajaran penjas.Hal tersebut dapat dilihat bahwa selama ini pembelajaran penjas dilakukan guru hanya dengan alat seadanya, padahal sarana dan prasarana yang dimiliki sekolah sangat sedikit sehingga pada waktu pembelajaran banyak siswa yang menganggur. Sehingga pembelajaran tidak tercapai atau tidak memuaskan. Dalam setiap pembelajaran penjas, siswa menunjukkan sikap yang kurang berminat dan antusias. Siswa terlihat bosan dan tidak menaruh perhatian sepenuhnya pada pelajaran karena model permainan yang dilakukan monoton.

Berdasarkan data awal rekapitulasi prestasi hasil belajar siswa dalam pembelajaran diperoleh bahwa:

1. Dari 23 orang keseluruhan jumlah siswa, terdapat 19 orang siswa atau sebanyak $82,61 \%$ yang belum tuntas dalam belajar.

2. Dari 23 orang keseluruhan jumlah siswa, terdapat 4 orang siswa atau 17,39\% yang sudah tuntas dalam pembelajaran.

3. Nilai rata-rata siswa mencapai 56,52

Penjelasan mengenai data kemampuan siswa pada kondisi awal berdasarkan hasil observasi pada pelaksanaan kegiatan pembelajaran sebagaimana dijelaskan tabel di bawah ini.

Tabel 4.2 Rekapitulasi Data Observasi Siswa Pada Observasi Awal

\begin{tabular}{c|l|c|c|c} 
No & $\begin{array}{c}\text { Kriteria } \\
\text { Aspek }\end{array}$ & $\begin{array}{c}\text { Jumlah } \\
\text { Aspek }\end{array}$ & Persentase & Ket \\
\hline $\mathbf{1}$ & $\begin{array}{l}\text { Baik } \\
\text { Sekali }\end{array}$ & 0 & 0,00 & \\
\hline $\mathbf{2}$ & Baik & 13 & 56,52 & \\
\hline $\mathbf{3}$ & Cukup & 7 & 30,43 & \\
\hline $\mathbf{4}$ & Kurang & 3 & 13,04 &
\end{tabular}

Dari tabel di atas terlihat bahwa pada kondisi awal data kemampuan belajar siswa dapat dijelaskan sebagai berikut:

a. Kategori baik sekali sebanyak 0 siswa atau $0 \%$

b. Kategori baik sebanyak 13 siswa atau $56,52 \%$

c. Kategori cukup sebanyak 7 siswa atau $30,43 \%$

d. Kategori kurang sebanyak 3 siswa atau $13,04 \%$

Dari observasi yang telah dilakukan menunjukkan bahwa tingkat kemampuan siswa masih rendah. Ini menunjukkan kecenderungan siswa masih biasa saja dalam proses pembelajaran atau kurang aktif.

2. Deskripsi Siklus I

Nilai hasil test pada siklus I diperoleh dari tes harian dengan jumlah soal sebanyak 10 soal, hasil itu dapat diketahui dalam gambaran sebagai berikut:

Tabel 4.3 Rekapitulasi Nilai Hasil Belajar Siswa Pada Pelaksanaan Siklus Pertama

\begin{tabular}{l|c|c|c|c|c|c} 
Nilai & Jumlah Siswa & Capaian & \multicolumn{5}{|c}{ Tuntas } \\
\cline { 4 - 7 } & & & Ya & \% & Tidak & \% \\
\hline $\mathbf{5 0}$ & 7 & 350 & & & $\sqrt{ }$ & 30,43 \\
\hline $\mathbf{6 0}$ & 6 & 360 & & & $\sqrt{ }$ & 26,09 \\
\hline $\mathbf{7 0}$ & 9 & 630 & $\sqrt{ }$ & 39,13 & & \\
\hline $\mathbf{8 0}$ & 1 & 80 & $\sqrt{ }$ & 4,35 & & \\
\hline $\mathbf{9 0}$ & 0 & 0 & & & & \\
\hline $\mathbf{1 0 0}$ & 0 & 0 & & & & \\
\hline Jumlah & $\mathbf{2 3}$ & $\mathbf{1 4 2 0}$ & - & $\mathbf{4 3 , 4 8}$ & - & $\mathbf{5 6 , 5 2}$ \\
\hline Nilai >= KKM & \multicolumn{7}{|c}{$\mathbf{4 3 , 4 8}$} \\
\hline Nilai Rata-Rata & $\mathbf{4 3 , 4 8}$ \\
\hline Tuntas & $\mathbf{5 6 , 5 2}$ \\
\hline Belum Tuntas & \multicolumn{7}{|c|}{$\mathbf{5 0}$} \\
\hline
\end{tabular}

Data di atas menunjukkan dalam siklus I ini sudah ada peningkatan kemampuan siswa dalam memahami materi dibandingkan pada pra siklus, namun belum sesuai dengan indikator 
yang ditentukan yaitu dengan KKM 70 siswa mendapat hasil $85 \%$ dari jumlah seluruh siswa, jika dilihat dari tingkat ketuntasannya ada 10 siswa atau $43,48 \%$ yang tuntas dan siswa belum tuntas sebanyak 13 siswa atau 56,52. Hal ini menunjukkan bahwa dilakukan belum sesuai dengan indikator yaitu minimal $85 \%$ dari jumlah seluruh siswa dinyatakan tuntas atau mendapat nilai minimal sama dengan KKM 70.

Setelah mengobservasi siswa selama proses pembelajaran di kelas dengan menggunakan instrumen observasi yang dipegang kolabolator yang terkait dengan kemampuan siswa dalam pembelajaran berpasangan kemampuan gerak dasar dalam permainan Rounders pada permainan Rounders didapatkan hasil dari bentuk kemampuan yang telah dilakukan oleh siswa sebagai berikut:

Tabel 4.4 Data Kemampuan Belajar Siswa Pada Pelaksanaan Siklus Pertama

\begin{tabular}{c|l|c|c|c} 
No & $\begin{array}{c}\text { Kriteria } \\
\text { Aspek }\end{array}$ & $\begin{array}{c}\text { Jumlah } \\
\text { Aspek }\end{array}$ & Persentase & Ket \\
\hline $\mathbf{1}$ & $\begin{array}{l}\text { Baik } \\
\text { Sekali }\end{array}$ & 10 & 43,48 & \\
\hline $\mathbf{2}$ & Baik & 8 & 34,78 &
\end{tabular}

\begin{tabular}{c|l|c|c|c}
3 & Cukup & 5 & 21,74 & \\
\hline $\mathbf{4}$ & Kurang & 0 & 0,00 &
\end{tabular}

Dari tabel di atas terlihat bahwa pada kondisi awal data kemampuan belajar siswa dapat dijelaskan sebagai berikut:

a. Kategori baik sekali sebanyak 10 siswa atau $43,48 \%$

b. Kategori baik sebanyak 8 siswa atau $34,78 \%$

c. Kategori cukup sebanyak 5 siswa atau $21,74 \%$

d. Kategori kurang sebanyak 0 siswa atau $0 \%$

Dari analisis data di atas dapat disimpulkan bahwa jumlah siswa tuntas sebanyak 18 siswa atau 78,26\% sehingga belum memenuhi kriteria dan indikator keberhasilan minimal $85 \%$ dari jumlah seluruh siswa dinyatakan tuntas.

3. Deksripsi Siklus II

Nilai hasil test pada siklus II diperoleh dari tes harian dengan jumlah soal sebanyak 10 soal, hasil itu dapat diketahui dalam gambaran sebagai berikut:

Tabel 4.5 Rekapitulasi Nilai Hasil Belajar Siswa Pada Pelaksanaan Siklus Kedua

\begin{tabular}{|c|c|c|c|c|c|c|}
\hline \multirow[t]{2}{*}{ Nilai } & \multirow[t]{2}{*}{ Jumlah Siswa } & \multirow[t]{2}{*}{ Capaian } & \multicolumn{4}{|c|}{ Tuntas } \\
\hline & & & Ya & $\%$ & Tidak & $\%$ \\
\hline 50 & 0 & 0 & & & & \\
\hline 60 & 3 & 180 & & & $\sqrt{ }$ & 13,04 \\
\hline 70 & 10 & 700 & $\sqrt{ }$ & 43,48 & & \\
\hline 80 & 10 & 800 & $\sqrt{ }$ & 43,48 & & \\
\hline 90 & 0 & 0 & & & & \\
\hline 100 & 0 & 0 & & & & \\
\hline Jumlah & 23 & 1680 & & 86,96 & & 13,04 \\
\hline Nilai >= KKM & & & 36,96 & & & \\
\hline Nilai Rata-Rata & & & 73,04 & & & \\
\hline Tuntas & & & 86,96 & & & \\
\hline Belum Tuntas & & & 13,04 & & & \\
\hline
\end{tabular}

Data di atas menunjukkan dalam siklus II ini terjadi peningkatan kemampuan siswa dalam memahami materi dibandingkan pada siklus I, yaitu dengan KKM 70 siswa mendapat hasil $85 \%$ dari jumlah seluruh siswa, jika dilihat dari tingkat ketuntasannya ada 20 siswa atau $86,96 \%$ yang tuntas, dan siswa belum tuntas sebanyak 3 siswa atau $13,04 \%$. Hal ini menunjukkan bahwa dilakukan belum sesuai dengan indikator yaitu minimal $85 \%$ dari jumlah seluruh siswa dinyatakan tuntas atau mendapat nilai minimal sama dengan KKM 70.
Setelah mengobservasi siswa selama proses pembelajaran di kelas dengan menggunakan instrumen observasi menggunakan 12 indikator yaitu posisi badan, posisi tangan, posisi kaki, gerakan tangan, gerakan kaki,arah bola, jauh dekatnya lemparan, melempar bola, menangkap bola, memukul bola, menghindar dan berlari yang dipegang kolabolator yang terkait dengan kemampuan siswa dalam pembelajaran berpasangan kemampuan gerak dasar dalam permainan Rounders pada permainan Rounders didapatkan 
hasil dari bentuk kemampuan yang telah dilakukan oleh siswa sebagai berikut:

Tabel 4.6 Data Kemampuan Belajar Siswa Pada Pelaksanaan Siklus Kedua

\begin{tabular}{l|l|c|c|c} 
No & \multicolumn{1}{|c|}{$\begin{array}{c}\text { Kriteria } \\
\text { Aspek }\end{array}$} & $\begin{array}{c}\text { Jumlah } \\
\text { Siswa }\end{array}$ & Persentase & Ket \\
\hline $\mathbf{1}$ & Aktif Sekali & 19 & 82,61 & \\
\hline $\mathbf{2}$ & Aktif & 4 & 17,39 & \\
\hline $\mathbf{3}$ & Cukup & 0 & 0,00 & \\
\hline $\mathbf{4}$ & Kurang & 0 & 0,00 & \\
\multicolumn{4}{|c|}{ Dari tabel di atas terlihat bahwa pada }
\end{tabular}
kondisi awal data kemampuan belajar siswa dapat dijelaskan sebagai berikut:

a. Kategori aktif sekali sebanyak 19 siswa atau $82,61 \%$

b. Kategori aktif sebanyak 4 siswa atau 17,39\%

c. Kategori cukup sebanyak 0 siswa atau $0 \%$

d. Kategori kurang sebanyak 0 siswa atau $0 \%$
Dari observasi yang telah dilakukan menunjukkan bahwa tingkat kemampuan siswa aktif. Ini menunjukkan kecenderungan siswa sudah aktif dalam proses pembelajaran dan mencapai indikator $85 \%$. Dimana ketuntasannya sudah mencapai 23 siswa atau $100 \%$.

Hasil didasarkan pada hasil pemilihan yang telah dilakukan dan diperoleh data sebagai berikut:

1. Kemampuan Belajar

Kemampuan belajar siswa tiap siklusnya mengalami peningkatan, hal ini diukur dari hasil pengamatan kolaborator yang terkait dengan kemampuan siswa dalam penggunaan strategi pembelajaran berpasangan merupakan strategi pembelajaran berpasangan yang dapat memudahkan siswa dalam melakukan gerak dasar dalam permainan Rounders. Kemampuan belajar siswa selengkapnya dapat dilihat dalam tabel berikut:

Tabel 4.8 Peningkatan Kemampuan Belajar Siswa pada Pra Siklus, Siklus I dan Siklus II

\begin{tabular}{c|c|c|c|c|c|c|c}
\multirow{2}{*}{ Nilai } & \multirow{2}{*}{ Kategori } & \multicolumn{2}{|c|}{ Pra siklus } & \multicolumn{2}{c|}{ Siklus I } & \multicolumn{2}{c}{ Siklus II } \\
\cline { 3 - 8 } & & Siswa & $\mathbf{\%}$ & Siswa & $\mathbf{\%}$ & Siswa & $\mathbf{\%}$ \\
\hline $\mathbf{0 - 3}$ & Baik Sekali & 0 & 0,00 & 10 & 45,45 & 19 & 86,36 \\
\hline $\mathbf{4 - 6}$ & Baik & 13 & 59,09 & 8 & 36,36 & 4 & 18,18 \\
\hline $\mathbf{7 - 9}$ & Sedang & 7 & 31,82 & 5 & 22,73 & 0,00 & 0,00 \\
\hline $\mathbf{1 0 - 1 2}$ & Kurang & 3 & 13,64 & 0 & 0,00 & 0,00 & 0,00 \\
\hline Jumlah & & $\mathbf{2 3}$ & $\mathbf{1 0 0}$ & $\mathbf{2 3}$ & $\mathbf{1 0 0}$ & $\mathbf{2 3}$ & $\mathbf{1 0 0}$
\end{tabular}

Dari tabel di atas dapat dijelaskan ketuntasan belajar siswa pada setiap tahapan siklusnya sebagaimana dijelaskan tabel di bawah ini

Tabel 4.8 Rekapitulasi Ketuntasan Belajar Siswa pada Pra Siklus, Siklus I dan Siklus II

\begin{tabular}{c|c|c|c|c|c} 
No & Siklus & Tuntas & $\mathbf{\%}$ & Belum Tuntas & $\mathbf{\%}$ \\
\hline $\mathbf{1}$ & Awal & 13 & 56,52 & 10 & 43,48 \\
\hline $\mathbf{2}$ & Siklus I & 18 & 78,26 & 5 & 21,74 \\
\hline $\mathbf{3}$ & Siklus II & 23 & 100,00 & 0 & 0,00
\end{tabular}

Dari tabel di atas secara lebih jelas dapat dilihat pada diagram batang di bawah ini:

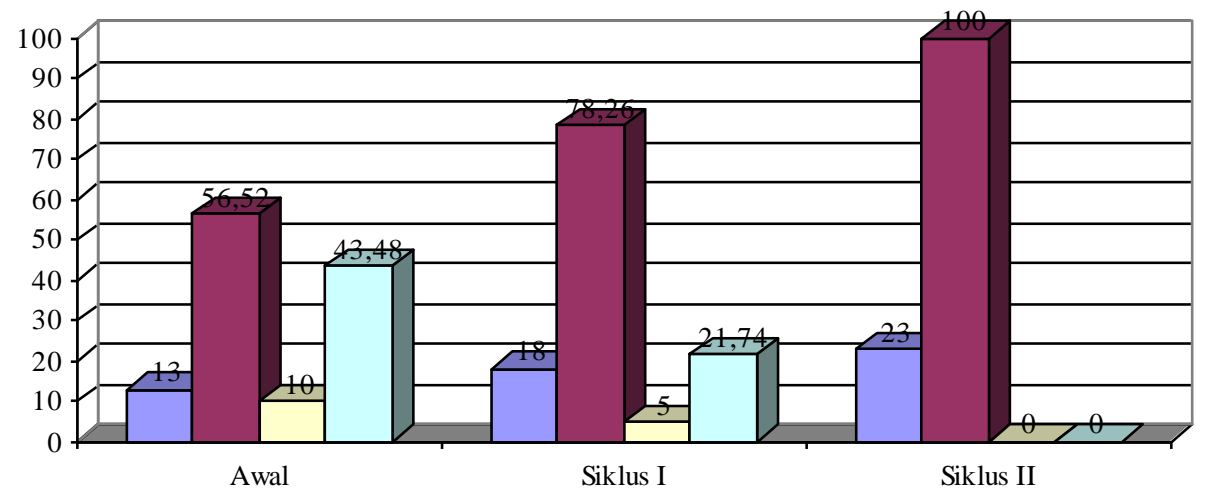

$\square$ Tuntas $\square \% \square$ Belum Tuntas $\square \%$ 


\section{Gambar 4.1 Peningkatan Ketuntasan Belajar Siswa pada Pra Siklus, Siklus I dan Siklus II}

Dari grafik dan tabel di atas menunjukkan bahwa penggunaan strategi pembelajaran berpasangan merupakan strategi pembelajaran berpasangan dalam melakukan gerakan dasar kemampuan gerak dasar dalam permainan Rounders dapat meningkatkan kemampuan belajar ini ditunjukkan dengan peningkatan kemampuan dasar bermain Rounders per siklus nya dimana pada kondisi awal hanya 13 siswa atau 56,52\%, siklus I ada 18 siswa atau $78,26 \%$, dan pada siklus II ada 26 siswa atau $100 \%$, hasil ini sesuai dengan indikator yang ditentukan yakni kategori aktif dan aktif sekali yang mencapai $85 \%$.

Berdasarkan hasil di atas menunjukkan terjadi peningkatan dari pra siklus, siklus I dan siklus II, dengan kata lain tindakan peneliti dalam penggunaan strategi pembelajaran berpasangan merupakan strategi pembelajaran berpasangan dalam melakukan gerakan dasar kemampuan dalam permainan Rounders dalam proses pembelajaran dan membimbing pada nilai ketuntasan belajar dan indikator yang diinginkan yaitu $85 \%$ tercapai.

2. Hasil belajar

Hasil belajar siswa tiap siklusnya mengalami peningkatan, hal ini diukur dari hasil tes yang dijawab oleh siswa, hasil belajar siswa selengkapnya dapat dilihat dalam tabel dan gambar berikut:

Tabel 4.7 Rekapitulasi Peningkatan Hasil belajar Pra Siklus, Siklus I dan Siklus II

\begin{tabular}{c|c|c|c|c|c|c} 
No & Siklus & Nilai & Tuntas & $\boldsymbol{\%}$ & $\begin{array}{c}\text { Belum } \\
\text { Tuntas }\end{array}$ & \% \\
\hline $\mathbf{1}$ & Awal & 56,52 & 4 & 17,39 & 19 & 82,61 \\
\hline $\mathbf{2}$ & Siklus I & 61,74 & 10 & 43,48 & 13 & 56,52 \\
\hline $\mathbf{3}$ & Siklus II & 73,04 & 20 & 86,96 & 3 & 13,04
\end{tabular}

Dari grafik dan tabel di atas menunjukkan bahwa penggunaan strategi pembelajaran berpasangan dalam melakukan gerakan dasar kemampuan gerak dasar dalam

permainan Rounders dapat meningkatkan hasil belajar ini ditunjukkan dengan peningkatan hasil belajar per siklus. Dalam bentuk diagram batang sebagaimana dijelaskan gambar dibawah ini:

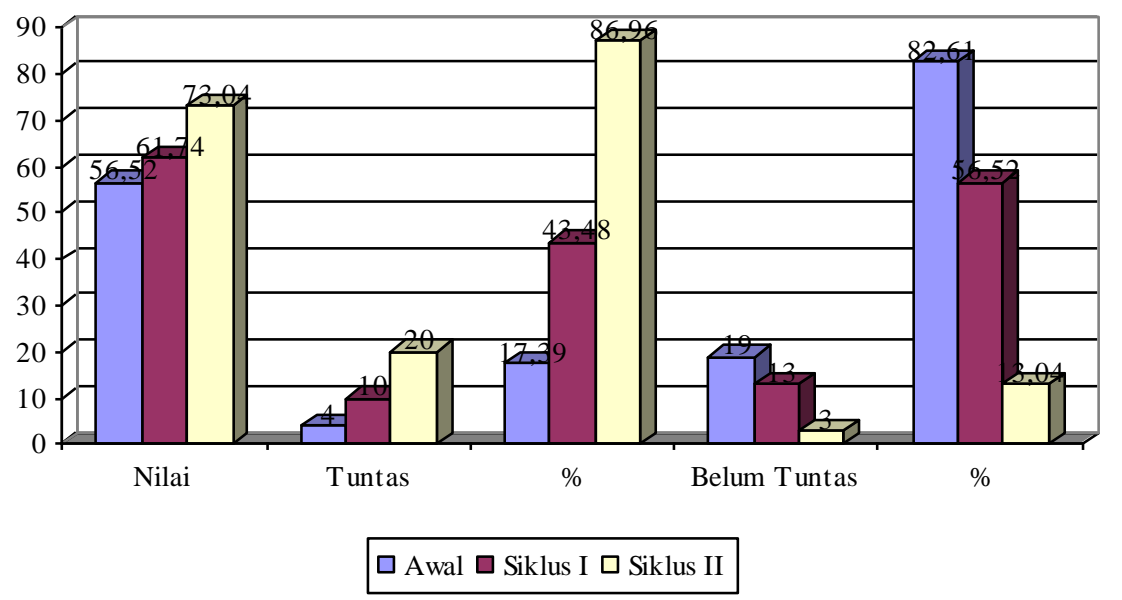

\section{Gambar 4.1 Peningkatan Ketuntasan Belajar Berdasarkan Nilai Tes Hasil Belajar pada Pra Siklus, Siklus I dan Siklus II}

Sebelum melaksanakan siklus I, peneliti melakukan survey awal untuk mengetahui kondisi yang ada di lapangan. Dari hasil kegiatan survey ini, peneliti menemukan bahwa kualitas proses dan hasil belajar berkaitan dengan kemampuan teknik dasar permainan Rounders masih rendah. Kemudian peneliti berupaya untuk mengatasi masalah tersebut dengan menerapkan strategi berpasnagan untuk meningkatkan hasil belajar permainan Rounders. Pada siklus I ternyata masih banyak kelemahan selama proses pembelajaran dengan menerapan strategi berpasangan. Siklus II dilaksanakan untuk mengatasi kelemahan pada siklus I. Selain 
itu, siklus II juga merupakan upaya meningkatkan hasil belajar pada siklus II dan ternyata tujuan khusus penelitian ini sudah tercapai pada siklus II. Dengan demikian penelitian ini hanya dilaksanakan dalam dua siklus. Selain itu, penelitian ini juga bermanfaat untuk meningkatkan kinerja guru agar setiap melaksanakan pembelajaran bisa lebih aktif, kreatif, efektif, inovatif, dan menyenangkan sehingga tujuan pembelajaran dapat tercapai sesuai target tang telah ditetapkan. Siswa sudah mampu melakukan memukul bola baik yang dilambungkan sendiri ataupun yang dilambungkan teman/lawan. Pengambilan nilai dari hasil tes yang dilakukan setelah selesai memberikan materi pembelajaran permainan Rounders menunjukkan peningkatan dari siklus I ke siklus II.

Pada awalnya siswa merasa kurang percaya diri dan kesulitan ketika harus melakukan teknik dasar memukul yang baik, tetapi peneliti selalu memberikan contoh gerakan yang baik dan menanyakan bagian mana yang sulit dilakukan. Kemudian peneliti memberikan penjelasan, diikuti dengan contoh gerakan yang baik dan benar. Dengan demikian siswa memahami kesalahan dan berusaha memperbaikinya dengan melakukan apa yang telah dicontohklan peneliti. Kemampuan menggunakan metode pembelajaran sangat diperlukan dalam proses pembelajaran karena dengan menggunakan metode pembelajaran apa yang ingin diajarkan kepada siswa mudah diserap. Siswa dikenalkan pada metode pembelajaran yaitu strategi berpasangan, pada umumnya siswa akan mengalami kesulitan dan ada rasa takut untuk melakukan gerakan memukul bola dalam permainan Rounders. Peneliti sudah mampu membangkitkan minat dan semangat siswa Semangat dan minat siswa terhadap pembelajaran permainan Rounders mengalami peningkatan jika dibandingkan sebelum menggunakan metode pembelajaran yaitu strategi berpasangan. Hal ini dapat dilihat dari proses pembelajaran siswan semangat dan antusias.

Tujuan pembelajaran jasmani adalah untuk membawa perubahan kearah positif pola pikir (kognitif) pola sikap (efektif) dan keterampilan dalam (psikomotor) siswa kearah yang lebih baik. Tujuan pendidikan jasmani harus mampu menunjang tujuan sekolah dan tujuan pendidikan pada umumnya misalnya perkembangan pribadi anak yang utuh dan mandiri, sehinggah mampu mengembangkan dirinya dan dapat membangun masyarakat di sekitarnya. Untuk tujuan kemandirian dan pengembangan dari anak dirangsang mampu mengutarakan pendapat atau pandangan yang keritis, obyektif, dan menghargai pendapat serta hasil pembahasan-pembahasan teman sejawat. Untuk mencapai tujuan itu, maka guru sebagai pelaku utama harus berusaha melibatkan siswa secara tepat terhadap suatu materi pelajaran dengan presentasi keterlibatan siswa yang tinggi dari waktu yang tersedia untuk mencapai tujuan tersebut salah satu usaha yang di perhatikan guru dalam proses pembelajaran adalah dengan memilih model pembelajaran yang mendukung terciptanya suasana belajar yang akrab dan ramah. Pada pembelajaran materi permainan khususnya mengenai kemampuan dasar melakukan lempar tangkap pada permainan Rounders untuk meningkatkan kemampuan dasar lempar tangkap pada permainan Rounders adalah dilakukan dengan cara guru menjelaskan, mempraktekkan dan menyuruh siswa untuk mempraktekan sendiri, sebagai hasil siswa akan memperoleh pengalaman belajar langsung melihat, melakukan, dan merasakan sendiri, yang diawali dengan cara melakukan lempar tangkap Rounders secara berulang-ulang. Hal ini akan mengakibatkan peningkatan kemampuan siswa dalam melakukan kemampuan gerak dasar dalam permainan Rounders pada permainan Rounders. Melalui metode berpasangan, ini terbukti bahwa siswa dapat meningkatkan kemampuan dasar melakukan kemampuan gerak dasar dalam permainan Rounders pada permainan Rounders.

Beberapa hasil di atas dapat dibahas bahwa ketika proses pembelajaran yang dilakukan dengan menekankan kemampuan siswa dan penuh motivasi akan menjadikan siswa mampu belajar dengan baik dan semakin dan pada akhirnya akan mampu meningkatkan kemampuan siswa dalam memahami materi. Keberhasilan belajar menurut model belajar ini bukan semata-mata ditentukan oleh kemampuan individu secara utuh, melainkan perolehan belajar itu akan semakin baik apabila dilakukan secara bersama-sama dan terstruktur dengan baik. Jadi ketika memaksimalkan belajar siswa untuk peningkatan prestasi akademik dan pemahaman baik secara individu maupun secara kelompok. dengan sendirinya dapat memperbaiki hubungan di antara para siswa yang heterogen dengan berbagai latar belakang etnis dan kemampuan, mengembangkan 
keterampilan-keterampilan proses kelompok dan pemecahan masalah.

Dari penjelasan di atas dapat ditarik kesimpulan bahwa melalui strategi berpasangan terbukti dapat meningkatkan kemampuan gerak dasar dalam permainan Rounders siswa kelas V SD Negeri 112 Pacciro Semester I Tahun Pelajaran 2017/2018.

\section{SIMPULAN DAN SARAN}

Berdasarkan penelitian yang disajikan dalam BAB IV dapat diambil kesimpulan sebagai berikut :

1. Penerapan strategi pembelajaran berpasangan terbukti mampu meningkatkan kemampuan gerak dasar dalam permainan Rounders siswa kelas V SD Negeri 112 Pacciro Peningkatan tersebut meliputi: suasana pembelajaran dan kemampuan memukul siswa. Hal ini dapat dilihat dari hasil pengamatan yang dilakukan oleh peneliti yang dibandingkan dengan observer pada saat proses pembelajaran berlangsung. Pada siklus I meningkatkan suasana pembelajaran dan kemampuan memukul dan pada siklus II dapat meningkatkan suasana pembelajaran dan kemampuan memukul dalam bemain Rounders. Suasana pembelajaran disini meliputi keaktifan, semangat dan ketekunan siswa dalam mengikuti pembelaran permainan Rounders.

2. Pembelajaran bola Rounders pada pembelajaran kemampuan gerak dasar dalam permainan Rounders melalui strategi pembelajaran berpasangan dalam meningkatkan kemampuan siswa yang ditunjukkan dari kondisi awal hanya 13 siswa atau $56,52 \%$, siklus I ada 18 siswa atau $78,26 \%$, dan pada siklus II ada 23 siswa atau $100 \%$, hasil ini sesuai dengan indikator yang ditentukan yakni kategori aktif dan aktif sekali yang mencapai $85 \%$.

3. Pembelajaran permainan Rounders melalui strategi pembelajaran berpasangan memiliki dampak positif dalam meningkatkan hasil belajar siswa yang ditandai dengan peningkatan hasil dan ketuntasan belajar siswa dalam setiap siklus, yaitu 4 siswa atau $17,39 \%$, pada siklus I mengalami kenaikan yaitu ada 10 siswa atau $43,48 \%$, dan pada siklus II ada 20 siswa atau 86,96\%, hasil ini sesuai dengan indikator yang ditentukan yakni nilai dengan KKM 70 di atas $85 \%$ dengan perolehan nilai rata-rata pada kondisi awal sebesar 56,52, meningkat menjadi 61,74 pada siklus pertama dan 73,04 pada siklus kedua.

Berdasarkan hasil penelitian dan kesimpulan yang telah peneliti paparkan di atas agar proses belajar mengajar lebih efektif dan lebih memberikan hasil yang optimal bagi siswa, maka peneliti sampaikan beberapa saran antara lain:

1. Untuk Siswa

a. Siswa senantiasa rajin mengikuti proses pembelajaran di sekolah dan jangan takut mencoba permainan Rounders.

b. Siswa hendaknya membiasakan diri untuk berolahraga demi menjaga kesehatan jasmani dan rohani.

2. Untuk Guru

a. Guru hendaknya menggunakan modifikasi metode pembekajaran sesuai dengan pembelajaran penjasorkes. Karena hal ini telah peneliti buktikan mampu meningkatkan hasil belajar siswa.

b. Guru hendaknya mengadakan latihanlatihan yang cukup dan dapat mengembangkan permainan sesuai dengan materi yang diajarkan.

c. Guru hendaknya bukan hanya menjadi orang yang hanya dapat bebicara tentang peningkatan mutu penidikan tetapi lebih berupaya melakukan tindakan nyata dalam perbaikan pembelajaran.

3. Untuk Sekolah

a. Perlunya pihak sekolah memberikan konstribusi dan keleluasan dalam pelaksanaan penelitian tindakan kelas salah satunya dalam meningkatkan kemampuan siswa dalam pembelajaran kasti, dan sekolah juga perlu memberikan media pembelajaran yang relevan dengan permasalahan pembelajaran.

b. Pentingnya sekolah dan dunia pendidikan, memberikan peluang dan dorongan kepada guru dan siswa untuk melakukan kegiatan kreatif dan inovatif dalam kegiatan Pendidikan Jasmani Olahraga dan Kesehatan yang menyenangkan.

\section{DAFTAR RUJUKAN}

Agus, Kristiyanto. 2010. Penelitian Tindakan Kelas PTK. Surakarta: UNSPRESS

Aminarni, dkk. 2007. Penjas Orkes untuk SD Kelas III. Jakarta: Erlangga.

Anita, Lie. 2005. Kooperatif Learning Mempraktikkan Cooperative Learning di. Ruang-ruang Kelas. Jakarta: Grasindo. 
Dadan, Heryana. 2010. Pendidikan Jasmani Olahraga dan Kesehatan. Jakarta: Pusat Pembukuan, Kementrian Pendidikan Nasional

Depdiknas, 2004, Kurikulum Pendidikan Dasar. Jakarta : Depdiknas.

Farida, Mulyaningsih dkk. 2010. Pendidikan Jasmani dan Kesehatan SD kelas IV. Jakarta: Pusat perbukuan Kemendiknas.

Hasan, Hamid. S. 2013. Evaluasi Kurikulum. Bandung: PT. Remaja RosdaKarya.

Juari, Wagino \& Sukiri. 2010. Pendidikan Jasmani Olahraga dan Kesehatan untuk SD/MI kelas V. Jakarta: Pusat Perbukuan Kementrian Pendidikan Nasional

Kurniadi, Deni \& Suro Prapanca. 2010 Pendidikan Jasmani, Olahraga, dan Kesehatan untuk sekolah Dasar/ Madrasah Ibtidaiyah Kelas IV. Jakarta: CV. Thursina.

Lutan, Rusli \& Agung Suherman. 1988. Perencanaan Pembelajaran Penjaskes, Depdikbud, Jakarta.

Nuh, Muhammad. 2013. Peraturan Menteri Pendidikan dan Kebudayaan Republik Indonesia Nomor 81A Tahun 2013 Tentang Implementasi Kurikulum. KEMENDIKBUD: 2013.

Sugiyono, 2006, Metode Penelitian Kuantitatif, Kualitatif dan $R \& D$, Penerbit Alfabeta, Bandung

Suharsimi A, Suhardjono \& Supardi. 2006. Penelitian Tindakan Kelas. Jakarta: PT Bumi Aksara.

Sukrisno, Aminarni dkk. 2007. Pendidikan Jasmani Olahraga dan Kesehatan. Semarang: Erlangga

Suyanto. 2004. Permainan Kecil. Jakarta: Departeman Pendidikan dan Kebudayaan Direktorat Jenderal Pendidikan Tinggi Proyek Pembinaan Tenaga Kependidikan. 